\title{
LINCHAMENTOS VIRTUAIS: ENSAIO SOBRE O DESENTENDIMENTO HUMANO NA INTERNET
}

\section{Eliane Tânia Freitas}

Mestre e doutora em Antropologia pela UFRJ, professora do Departamento de Antropologia e do Programa de Pós-Graduação em Antropologia Social da UFRN.E-mail: etmart@gmail.com

\section{RESUMO}

Este artigo baseia-se na observação sistemática de polêmicas públicas nas mídias sociais sobre conflitos ou práticas violentas nas redes sociais, denominados "linchamentos virtuais". Parto da descrição de um desses eventos, ocorrido em maio deste ano (2017), para, a partir daí, refletir sobre alguns elementos presentes em sua configuração, como a analogia com os linchamentos, a destruição de reputações, o ódio e a desconfiança. Para isso, apelo a noções como "audiências invisíveis" e hiperconectividade das redes sociais, a fim de destacar as especificidades de suas dinâmicas interativas e fornecer um contexto que possa esclarecer as razões da percepção aparentemente generalizada, na própria internet, de sua disseminação e intensificação. Por fim, ensaio brevemente distinguir entre formas diversas de conflitos/agressões on-line, conforme a uma classificação que distingue linchamentos virtuais de discurso de ódio, de acordo com seus modos de operação e finalidades.

Palavras-chave: linchamento virtual; discurso de ódio; redes sociais; internet; conflito. 


\section{ABSTRACT}

This article is based on systematic observation of public controversies in social media about conflicts or violent practices in social networks, called "virtual lynchings". I start from the description of one of these events, which took place in May of this year (2017), to reflect on some elements present in its configuration, such as the analogy with lynchings, the destruction of reputations, hatred and mistrust. I appeal to notions such as the invisible audiences' and hyperconnectivity of social networks in order to highlight the specificities of their interactive social dynamics and provide a context that can possibly clarify the reasons for the apparently generalized perception on the Internet of its dissemination and intensification. Finally, I briefly try to distinguish between different forms of online conflict /aggression, according to a classification which distinguishes virtual lynchings from hate speech, according to their modes of operation and purposes.

Key Words: virtual lynchings; hate speech; social networks; internet; conflict.

\section{Introdução}

Tive que me desculpar pela ignorância. Nunca havia ouvido falar nesta mulher, professora, que tem mais de 150 mil seguidores na Internet. Soube da sua existência, ou comecei a ser apresentado ao seu nome, quando, na noite de quarta-feira (3), minha TL passou a ser invadida por focos luminosos. Parecia vagalume batendo na tela. Cada qual com uma posição - contra ou a favor. Percebi ali que uma tal de Elika Takimoto experimentava um revés daqueles... Já vi muitos! ${ }^{1}$

Lau (2017). 
O jornalista Fábio Lau, ao manifestar seu desconhecimento sobre a identidade e atuação de Elika Takimoto ${ }^{2}$, a despeito dos seus 150 mil seguidores, não se encontra só nessa situação. Este foi, aliás, um dos elementos recorrentes nos artigos on-line que percorri acerca do episódio descrito por eles como "linchamento virtual" da blogueira Elika Takimoto. Essa alegação aponta para a heterogeneidade e complexidade das redes on-line e para a impossibilidade de totalizá-las a partir de uma experiência individual de inserção e interação nelas, que só pode ser parcial e incompleta.

Takimoto esteve, no início de maio de 2017, no centro de uma polêmica nas redes sociais. Neste caso, o episódio em questão teve lugar no Facebook e foi iniciado, de certo modo, pela agência da própria plataforma, ao tornar presente uma possibilidade dada na sua atual configuração, por meio de uma funcionalidade técnica que permite ao usuário a escolha de republicar ou não uma de suas postagens publicada naquela mesma data há um ano. Ao acatar essa sugestão diariamente apresentada pela plataforma ao usuário - neste caso, de rever e republicar no Facebook um artigo originalmente publicado em seu blog ${ }^{3}$ sobre suas experiências como professora no CEFET (Rio de Janeiro) com os primeiros alunos ingressantes através do sistema de cotas -, Takimoto não imaginava a tempestade que viria a cair sobre sua cabeça e que se tornaria, nos dias e semanas que se seguiriam, o assunto mais comentado nas suas redes sociais na internet e, dada a dimensão tomada pela polêmica, mesmo fora delas.

Foram registradas 38 mil curtidas - cliques no botão "curtir", que expressa aprovação ou outra reação, como tristeza, espanto, raiva, diversão

\footnotetext{
Filósofa, historiadora da ciência e física. Ensina física no CEFET-RJ. Vencedora do Prêmio Saraiva Literatura, categoria: crônicas. Autora do blog Minha Vida é um Blog Aberto e de dez livros, dentre eles História da Física na Sala de Aula, Minha Vida é um Blog Aberto, Como Enlouquecer seu Professor de Física, Filhosofia, Isaac no Mundo das Partículas, Beleza Suburbana e Tenso, Logo Escrito (Da seção Sobre Mim do seu blog Minha Vida é um Blog Aberto). Disponível em: <https://likatakimoto. com/>. Acesso em: 04 maio 2017.

3 A publicação original foi deletada do blog pela autora, mas é possível encontrá-la em vários dos blogs e sites que a republicaram, em 2016 e 2017. Você pode lê-lo, por exemplo, no Tijolaço, em publicação de maio de 2016, logo após sua publicação no blog de Takimoto: <www.tijolaco.com.br/ blog/que-escola-que-me-deu-tudo-possa-dar-tudo-todos/>.
} 
- na postagem sobre cotas original de 2016 (2 de maio), quando compartilhada no Facebook pela primeira vez. Muitas dessas reações e comentários criticavam ou antagonizavam a autora de algum modo, quanto ao teor e à forma como era tratado nele o tema das cotas raciais na escola pública. Memes e sátiras em formatos variados circularam sobre seu "racismo" e muitos focavam na frase "lembro-me que levei um susto ao entrar na sala. Havia negros e alunos". A frase completa, no seu blog, era "Havia negros e alunos extremamente diferentes na forma de se expressar".

As reações ao texto - ou melhor, aos alegados racismo e elitismo - da autora escalaram rapidamente a tal ponto que ela veio a público, já no dia seguinte (03/05), pouco depois de meio-dia, em novo texto no blog, republicado em seus perfis no Facebook e Twitter, anunciar que desativaria sua conta no Facebook, onde as mensagens mais intimidadoras, inclusive com divulgação de seus dados privados (como seu endereço residencial), haviam ocorrido. Mais uma vez, também esse texto ecoou por vários sites/blogs, inclusive alguns muito conhecidos dentre pessoas que se identificam - como Takimoto - como "de esquerda" - como o Tijolaço, o DCM, o GGN e o Esquerda Caviar ${ }^{4}$. No entanto, na ocasião da segunda publicação, o texto extrapolou, e muito, esses segmentos da Rede por onde os escritos da blogueira normalmente circulam e encontrou - ou, antes, foi encontrado por - "nova" audiência, que o leu a partir de preocupações e pressupostos outros, inesperados e imprevistos pela autora e seus leitores assíduos e contatos mais próximos.

É dessas reações, a começar pela reação da própria Takimoto ao anunciar o abandono da rede social Facebook, que passarei a falar a seguir. Meu objetivo principal é, a partir da descrição desse "caso", neste momento a partir do ponto de vista da própria autora-blogueira alvo dos ataques, refletir sobre suas repercussões e, contextualizando-o no quadro mais amplo de eventos similares e discursos correntes sobre agressões e conflitos on-line, tentar discernir os motivos pelos quais hoje parece estar se formando

${ }^{4}$ Artigos sobre a polêmica: Gomes (2017), Gruner (2017) e Miguel (2017). 
um amplo consenso acerca da crescente disseminação desse tipo de prática agressiva na internet, principalmente nas redes sociais (como o Facebook). A analogia com linchamentos e sua rejeição como prática bárbara ao mesmo tempo parece contribuir para seu reforço, inclusive na mesma medida em que conforma um modo de olhar para eles que acaba por ser reproduzido de modo naturalizado e irrefletido. $\mathrm{O}$ tom de alguns artigos que discutem esses eventos exemplifica bem o que a literatura sociológica chama pânico moral. Por fim, na última seção, procuro capturar alguns elementos gerais distintivos dos linchamentos virtuais e distingui-los do discurso de ódio quanto aos seus modos de operação e finalidades.

\section{"Até um dia, Facebook"}

Li o texto. Reli. Li comentários. Muitos xingamentos, muitas agressões. A minha reação é ficar desesperada olhando para o que fiz e questionando onde errei [...].

Esse é o título da postagem, no estilo carta de despedida, que Elika Takimoto escreveu e publicou em seu blog Minha Vida é um Blog Aberto republicada depois por outros blogs e sites, cujos links foram, por sua vez, compartilhados nas páginas pessoais de seus leitores em redes sociais como Twitter e Facebook. Nela, a autora explica o porquê de haver desativado sua conta no Facebook, o que Fábio Lau, citado na epígrafe, resumiu assim: “[...] onde avisa que sai da Internet por conta das pancadas que sofreu". Ela enfrentava naquele momento muitas críticas, insultos e algumas ameaças, e a solução que encontrou foi o que Recuero, em um artigo sobre conversação nas redes sociais e "ameaças à face" - referência a Erving Goffman (1967 apud RECUERO, 2013) ${ }^{6}$ - e, portanto à reputação pessoal, causadas por comportamentos violentos nas redes sociais, apontou como uma das duas al-

5 Disponível em: <https://elikatakimoto.com/2017/05/03/ate-um-dia-facebook/>.

6 "A face é uma imagem do self delineada em termos de atributos sociais aprovados" (p. 58). 
ternativas das vítimas: escancarar o conflito e partir para o flaming $^{7}$, a briga, ou recolher-se e silenciar para evitar danos ainda maiores ${ }^{8}$.

Como já foi dito, o Facebook apresenta uma funcionalidade que convida o usuário a republicar alguma postagem publicada um ano antes, naquela mesma data. Se não quer republicar, ou mesmo abrir e reler ou rever (podem ser fotos ou vídeo), o usuário pode optar por ocultar a postagem e seguir adiante, na sua rotina de leituras, comentários, compartilhamentos, curtições e outras interações facebookianas, mas, se relê ou revê o post antigo sugerido e sente vontade de republicá-lo, só precisa de um clique e estará feito. Takimoto provavelmente veio a lamentar que tenha sido esta sua escolha, devido às inesperadas - e ela não cessou de enfatizar isso - consequências da republicação do "texto sobre as cotas", como ficou conhecido no disse-que-disse das redes.

O texto sobre cotas me apareceu como "lembrança do Facebook". Como acontece com inúmeros deles, apenas dei o famoso control C control $\mathrm{V}$ para quem não tivesse lido, caso quisesse, dar uma olhada. Lembrome que, no ano passado, recebi mensagens de todo o Brasil por ele. Pessoas que haviam sido (ou ainda eram) cotistas estavam me agradecendo emocionadas pelo relato que eu havia feito. Por recordar as mensagens de carinho que havia recebido e por entender que ele seria algo bom para a comunidade, resolvi publicálo em meu feed mais uma vez. [...] Qual foi minha surpresa que dessa vez a minha vida virou de cabeça para baixo. Levei um susto com a quantidade de pessoas me agredindo e as ameaças que recebi. Fui acusada de ser racista e ter sido completamente infeliz nas palavras [...]. Perguntei-me: onde fui racista? Eu? Racista?! Já sabendo de pronto que sim, vale observar. Tinha sido racista já que há negros que se sentiram ofendidos. Essa é a regra. (TAKIMOTO, 2017).

Dery, Mark (1994).

8 "Goffman (1967) argumenta que esse risco pode levar desde a tentativas de salvaguarda da face até mesmo o recolhimento do ator que não participa da interação para não sofrer essas ameaças” (p. 59). 
Para sua surpresa e, como ela diz, susto, o que no ano anterior havia sido recebido de modo praticamente unânime por elogios e agradecimentos emocionados, tornou-se rapidamente o vórtice de uma tempestade de insultos, ameaças pessoais e exposição não consentida de sua privacidade, com a divulgação de seu endereço, CPF e contracheque on-line.

Como afirma Recuero (2013), o prejuízo à reputação e o silenciamento do membro de um grupo, decorrente da "desestabilização de sua face", repercutiriam sobre o capital social de todo o grupo, que decresceria?

A ameaça à face, portanto, nessas ferramentas, torna-se potencialmente mais danosa, uma vez que é mais pública por conta da hiperconexão, mais replicável, mais permanente (como as características dos públicos em rede) e, igualmente, mais abrangente em termos de rede. Uma ofensa, assim, é potencializada pela própria rede e pela capacidade da rede de reproduzir o caso e amplificar seus efeitos para os envolvidos." (p. 65)

A blogueira progressista estava sendo, naquele momento, chamada de racista, dentre outros nomes menos publicáveis - todavia, publicados -, e, assim, por tabela, todos os que a haviam elogiado um ano antes e agora, na ocasião da republicação do texto, viam-se colocados em xeque, obrigados a refletir sobre os efeitos sobre si, sobre suas próprias reputações, mas também sobre suas próprias posições acerca do assunto em pauta. De todos os lados, parecia haver convicção acerca de possíveis mal-entendidos, inclusive próprios, e isso parece ter feito tremer as redes - não necessariamente coincidentes, embora parcialmente sobrepostas - aglutinadas em torno dos perfis de Takimoto nas redes sociais (Facebook, Twitter e Blog). De moça simpática, politizada e progressista, ela passava, de súbito, a elitista, racista e até eugenista, o que trazia, para todos os que se percebiam de algum modo implicados na situação, aquilo que Airton Jungblut (2015) vem apontando 
em seus trabalhos como um dos traços característicos das experiências de debates e ações políticas na internet: a necessidade de reflexividade. Neste caso, no duplo sentido de esforço deliberado e consciente de reflexão sobre o que estaria ocorrendo naquele episódio, e suas possíveis implicações - como o que ele poderia nos ensinar sobre debates políticos na internet -, e também, eu acrescentaria, no sentido de ver-se refletido na situação vivida pelo outro e, ainda, ver-se pelos olhos de outros, muitos dos quais indivíduos com quem se mantém pouco ou nenhum contato, outros completamente desconhecidos.

Mas, afinal, o que teria mudado no intervalo de um ano, entre a primeira (02/05/2016) e a segunda (02/05/2017) publicação do texto sobre cotas? A própria Takimoto tem consciência da ampliação de sua audiência ${ }^{10}$ no intervalo entre a primeira e segunda postagem, segundo ela, como decorrência da viralização de postagens triviais e bem-humoradas sobre seus filhos e da nada trivial repercussão das notícias sobre o telefonema do ex-presidente Luiz Inácio Lula da Silva para ela ${ }^{11}$, em março, por sua vez justificado por sua assessoria como resposta a uma postagem em seu blog ${ }^{12}$ sobre os benefícios trazidos pelos governos do PT.

Danah Boyd (2007) ${ }^{13}$ vem estudando as redes sociais em termos de uma dinâmica mais abrangente do que ela denomina "networked publics". Recuero (2013, p. 54) resume sua caracterização: permanência das interações (continuariam acessíveis on-line); devido à permanência, sua buscabilidade (seria possível localizá-las via mecanismos de busca); em decorrência das

${ }_{10}$ “Como já disseram, sou uma 'subcelebridade' na internet. Para quem não sabe, esse boom no meu perfil ocorreu no ano passado por postagens de cunho bem diferentes terem viralizado: vídeo de minha filha cantando para vacas, foto dos meus filhos no aniversário Guanabara, texto relatando a minha experiência com coletor menstrual, anúncio de meu filho Hideo... e o polêmico texto sobre cotas escrito há um ano (repostado ontem no Facebook), que é o motivo dessa minha fala agora aqui" (TAKIMOTO, 2017).

${ }_{11}$ "Professora recebe telefonema de Lula após texto viral", 03 mar. 2017. Disponível em: <https:// www.pragmatismopolitico.com.br/2017/03/professora-recebe-telefonema-de-lula-apos-texto-viral.html>. Acesso em: 03 mar. 2017.

12 "Prometo não tocar no assunto", 24 fev. 2017. Disponível em: <https://elikatakimoto. com/2017/02/24/prometo-nao-tocar-no-assunto/comment-page-2/>. Acesso em: 03 mar. /2017.

13 O nome em minúsculas é singularidade da assinatura profissional escolhida pela autora. 
duas primeiras características, sua replicabilidade; e, por fim, sua escalabilidade, ou seja, "a presença das audiências invisíveis".

A hiperconexão das redes no Facebook e de outras redes sociais on-line resultaria de práticas de "apropriação" (RECUERO, 2013, p. 54) por parte de seus usuários, isto é, da multiplicação dos contatos nessas redes por meio da adição de conhecidos com quem não se tem, nem se passará a ter necessariamente, qualquer tipo de vínculo social ou mesmo interação direta. Vale lembrar que as próprias plataformas digitais de interação estão cada vez mais interligadas e que elas próprias, em seu agenciamento maquínico dos cadastros de perfis de novos usuários, encarregam-se de localizar contatos potenciais, já constantes em alguma lista de contatos anterior do novo usuário em outra plataforma, site ou aplicativo - por exemplo, no e-mail que já utilizamos. Existem também aplicativos cuja função é multiplicar rapidamente o número de contatos ou seguidores de um usuário, o que pode ser, conforme o ambiente social, um dado relevante para a elevação de seu capital de prestígio ${ }^{14}$ ou, nos termos escolhidos por Recuero, seu capital social.

Quanto maior o número de conexões que alguém mantém, mais sua rede (como totalidade) estaria próxima de outros atores e de outros segmentos de redes, segmentos esses que se organizariam em torno de outras afinidades, outros valores, outras experiências, talvez até outras noções de etiqueta $^{15}$.

Tendo em mente essas considerações sobre as redes sociais, voltemos, então, à Takimoto e deixemos que ela mesma nos conte o que lhe parece ter mudado em sua experiência on-line entre 2016 e 2017:

O fato de ter virado conhecida pouco me importa, ao contrário do que muitos (que não me conhecem) pensam. Coisas imprevisíveis que acontecem na internet... Por mim, ficaria falando só para meus

\footnotetext{
Por exemplo, PETROSILLO, 2016, p. 36.

15 Como se torna claro na discussão sobre quebra da polidez e consequente ameaça à face realizada por Recuero. A polidez é rompida, nas redes sociais, "principalmente por meio do trolling e da violência”. Quebrar a polidez é romper as normas da conversação (RECUERO, 2013, p. 60).
} 
amigos, como sempre fiz. "Printando meus próprios tweets" para eles somente no intuito de compartilhar ideias e brincar - como muitos sabem que gosto demais de fazer.

A única coisa que sempre sonhei foi ter meus livros publicados e só. Isso não escondo de ninguém. Mais do que isso para quê? Acabou que hoje tenho quase 150 mil seguidores, fato que foge à minha compreensão e ao meu controle. Quando penso nesse número me dá até calafrios. E, por tentar sublimá-lo e acreditar sempre que escrevo para meia dúzia de leitores, não tomo cuidados que hoje, aprendi, preciso estar atenta.

"Ficaria falando só para meus amigos, como sempre fiz", mas ela sabe que isso já não lhe é mais possível e que considerável parcela de seus seguidores/curtidores é constituída pelo que danah boyd (2007) chamou audiências invisíveis, ou seja, aqueles conhecidos - e conhecidos de conhecidos - que não chegam a interagir diretamente com ela e aqueles que acessam suas postagens indiretamente, por meio de links dos seus próprios contatos. Sua percepção disso se traduz na conclusão: "Prometo me policiar muito mais na minha fala, na minha escrita e a rever sempre meus (pre)conceitos".

Em outras palavras, em redes hiperconectadas, sua audiência sempre poderá ultrapassar suas previsões, expectativas e sua compreensão. A menos que aceite os riscos de ver-se envolvido no que Dery (1994) chama flame wars e esteja disposto a arcar com possíveis prejuízos à sua reputação, ao usuário resta o exercício do autocontrole e intensificação da reflexividade nas práticas on-line. Isso nos fornece pistas sobre o controle social em operação nas redes públicas on-line, a partir dos efeitos vivenciados pelos usuários. Esse controle é efetuado não apenas pelos administradores das plataformas e outros serviços on-line, ou pela tão discutida vigilância por parte de agências governamentais, mas também pelos limites colocados pelos usuários envolvidos em dinâmicas interativas de mútua vigilância ${ }^{16}$.

16 O que explicaria a prevalência nas redes sociais do que Jair Ramos (2015) chama realismo identitá- 
Outra implicação da ampliação das audiências seria a exposição ao risco de leituras descontextualizadas, porque realizadas não apenas a partir de outras lentes valorativas - porque a partir de outros segmentos de rede e clusters que se reúnem em torno de outras vivências e pertencimentos sociais -, mas também possivelmente a partir de sua captura deliberada por agendas ideológicas que podem ressignificar a mensagem recebida para que se preste aos seus próprios objetivos.

\section{Ódio, vergonha e humilhação: 0 que temos cultivado?}

Mesmo uma prática popularmente adjetivada como arcaica, bárbara e residual - no sentido de vestígio de antigas formações sociais e históricas, tida como incompatível com a modernidade e a civilização (SINGER, 2003; MARTINS, 2015) -, como é o linchamento, já encontrou seu caminho nas plataformas digitais on-line. E esse caminho é de mão dupla. O melhor exemplo disso é o "linchamento do Guarujá", no estado de São Paulo, ocorrido dia 3 de maio de 2014. O episódio, que culminou no espancamento e morte de Fabiane Maria de Jesus, 33 anos, teria sido deflagrado por um retrato falado divulgado nas redes sociais de suposta sequestradora de crianças a quem também se atribuía, nas postagens, a finalidade de exploração das crianças em rituais de magia negra. Esse retrato, portanto, mobilizava, nas plataformas digitais, signo das modernas sociedades hiperconectadas, todo um imaginário tradicional de caça às bruxas - aplicável sobretudo ao gênero

rio ou práticas de convergência identitária. Isso significa que, para reduzir a desconfiança e a insegurança nas interações, espera-se, nessas redes, coincidência entre a identidade online e a off-line, o que não deixaria margem para experimentações identitárias por meio da construção de personas vividas apenas on-line, como seria possível em mundos virtuais (Second Life, por exemplo) ou jogos. Isso ocorreria porque a divergência identitária estaria associada, devido à intensificação da percepção de riscos on-line, à possibilidade de fraude e outras ameaças. De fato, observei que o anonimato e o uso de perfis fakes têm sido associados ao aumento das práticas on-line consideradas violentas, como as que têm sido denominadas linchamento virtual, humilhação, shaming, discurso de ódio, assédio virtual. Talvez por isso, aliás, a primeira preocupação de Takimoto em sua resposta ao que percebeu como ameaça tenha sido, nas primeiras linhas de seu texto-resposta, afirmar sua autenticidade e sinceridade. "Há tempos escrevo sobre tudo o que me toca da forma mais sincera possível. Não tenho vergonha de falar de minhas fraquezas, de meus medos, de meus devaneios sejam eles de que natureza forem" (TAKIMOTO, “Até um dia, Facebook", 2017). 
feminino -, e isto, como se pode ver, em mais de um sentido, pois tratava-se de procurar e localizar uma bruxa, uma criminosa (sequestradora) e de incitar perseguição. O anúncio, veiculado no Facebook, parece ter colocado em movimento um dispositivo sociotécnico (JUNGBLUT, 2015) que, uma vez disparado, terminaria encontrando seu alvo, ainda que para isso precisasse fabricar um. Um dos presentes no linchamento o filmou e disponibilizou o vídeo no YouTube, perfazendo, assim, o caminho de volta às redes on-line e fechando o circuito instaurado pelo anúncio.

Tendo em mente esse entrelaçamento entre nossas experiências on-line e off-line, talvez seja possível alcançarmos mais clareza para a compreensão do uso da analogia que constitui a noção de linchamento virtual e, principalmente, sua rápida adoção e disseminação no Brasil. Mesmo Elika Takimoto, que não chega a utilizar essa expressão naquele texto "Até um dia, Facebook", expressa-se, ao falar das reações à sua postagem, em termos semelhantes, que tornam presente a analogia:

Não vou me ater aqui a dissecar o texto e a comentar frases que recortaram, colaram em fotos minhas e divulgaram em páginas e sites por aí. Sei que com isso minha integridade física já foi ameaçada, corro risco de vida, pois conhecem bem meu rosto (como fizeram questão de expor) e esses que fizeram isso querem mesmo a minha morte seja ela real seja metafórica. As duas são possíveis e se temo a primeira é porque sou mãe de três e filha de duas pessoas para as quais dou total assistência.

Ou ainda, no pós-escrito, acrescentado à postagem:

Publiquei esse texto me retratando publicamente. As ameaças, incrivelmente, pioraram depois que o escrevi. Por motivo de segurança (já que meu contracheque, meu CPF e endereço foram publicados junto com a foto do meu rosto com a legenda "racista!") e por precisar digerir tanto ódio sem afetar a minha saúde, desabilitei a minha 
conta por tempo indeterminado. Preciso me fortalecer. Obrigada a todos que permaneceram ao meu lado e não atiraram pedras.

Os artigos que condenam o que perceberam como agressões e ameaças a Takimoto afirmam que ela estaria sendo vítima de um linchamento virtual, frisando, inclusive, com bastante frequência, a banalidade desse tipo de prática nas redes sociais. Uma espécie de consenso entre blogueiros, jornalistas e outros formadores de opinião parece vir se constituindo em torno dessa ideia, frequentemente justificada pelo lugar comum: pensam que a internet é terra de ninguém. Não raro essa linha de raciocínio encaminha seu autor para a aparentemente inevitável conclusão de que seria necessária melhor regulamentação jurídica da Rede e maior controle sobre seus usuários.

Essa demanda, e seus pressupostos, não é nova, e parece ecoar outra, mais antiga, de maior controle social ${ }^{17}$ sobre os habitantes das cidades, especialmente sobre aqueles que vivem em condições precárias de pobreza e marginalidade social e são vistos, por isso, como perigosos e descontrolados - os que não saberiam se comportar, os incivilizados, antissociais e, no limite, violentos ${ }^{18}$. O mecanismo ideológico de construção e intensificação, junto a certo segmento da opinião pública, da percepção de perigo iminente, bem como de um inimigo público que encarnaria esse perigo, também não é algo novo. Talvez a novidade aqui seja o modo como esse mecanismo, conhecido como pânico moral (THOMPSON, 2002), que até então tinha como um de seus principais agenciadores e promotores as mídias de massa, vem sendo acionado na esfera pública hiperconectada, por meio de mídias reticulares, descentralizadas, altamente segmentadas, e como elas podem estar sendo potencializadas nas redes sociais devido justamente àquelas suas caracterís-

17 Para um exemplo, dentre tantos possíveis na bibliografia sobre linchamentos e sobre violência, ver o depoimento de Helio Bicudo citado por Helena Singer na p. 231 do seu livro (2003).

18 Ao caracterizar as vítimas mais frequentes de linchamentos no Brasil, com base em levantamento quantitativo de notícias sobre linchamentos nos jornais, José de Souza Martins (2015) chegou à constatação de que, ao lado da raça (maioria de negros e mestiços), ocupação (desocupados ou "vadios") e faixa etária (jovens, menores de idade), a reputação de antissocial já as estigmatizava em seu meio social. 
ticas singulares apontadas por pesquisadores como Recuero (2013) e boyd (2007).

Não pretendo, com essa referência ao pânico moral, minimizar os possíveis perigos que possam estar inscritos em práticas de exposição não consentida de privacidade, agressões verbais ou ameaças de morte. Há inúmeros acontecimentos públicos que dão testemunho de sua gravidade. Falarei sobre alguns deles a seguir. Porém, o que desejo ressaltar aqui, sobretudo, é o caráter inescapavelmente social e histórico de noções e práticas de violência, agressão e conflito (SOARES, 1996; SIMMEL, 1971) e dos modos como lidamos com elas, que consistem, afinal, em negociações de pertencimentos e exclusões sociais e disputas de sentido, sempre sujeitos a rearranjos e reformulações, além, é claro, da sua variabilidade, conforme o contexto sociocultural e o desenrolar dos acontecimentos, ou seja, sua percepção e compreensão poderá mudar ao longo do tempo, na medida em que novas experiências sociais se somem e articulem, de modo significativo, a esses contextos.

O escândalo internacional que envolveu Monica Lewinski e o então presidente dos Estados Unidos, Bill Clinton, é não apenas um dos mais famosos como goza hoje do status de haver inaugurado - pelo menos, em escala internacional - o assédio virtual, essa espécie de campanha difamatória que se vale das ferramentas técnicas digitais e do potencial multiplicador sem precedentes da internet. Como a própria Lewinsky recorda em uma palestra realizada em 2015 e ainda acessível on-line ${ }^{19}$, quando foi envolvida ${ }^{20}$ no escândalo sexual com o presidente Clinton, em 1998, não havia redes sociais. No entanto, isso não a impede de afirmar que a internet teria sido o elemento catalizador central do massacre ${ }^{21}$ moral sofrido por ela e de, por isso, apresentar-se como "a

19 LEWINSKY, Monica. The Price of Shame (O Preço da Vergonha). Disponível em: $<$ https://www.ted. com/talks/monica_lewinsky_the_price_of_shame $>$. Sobre a repercussão da palestra no Facebook: $<$ https://ideas.ted.com/want-to-help-prevent-online-bullying-comment-on-facebook/>.

${ }_{20}$ Digo "foi envolvida" porque um escândalo é um artefato, fabricado pela convergência de interesses de diferentes agentes e instituições sociais. Uma transgressão moral nem sempre se torna um escândalo público e, quando se torna, há nele sempre mais do que as escolhas, ou erros, individuais.

${ }_{21}^{21}$ "Quando a história apareceu, ela apareceu on-line. Foi uma das primeiras vezes em que a notícia tradicional foi sequestrada pela internet no caso de um acontecimento importante [...]. De pessoa 
paciente zero" do assédio virtual. Os efeitos, todavia, não foram apenas morais para ela e outras pessoas ${ }^{22}$ atingidas por exposição e perseguição na internet. A demissão, a dificuldade de conseguir um novo emprego, a necessidade de mudar de endereço para fugir a agressões e rejeições, a perda das amizades, o ostracismo social, a humilhação e a depressão estão dentre as consequências frequentemente citadas, conforme a gravidade da situação.

Proliferam atualmente nos sites jornalísticos e redes sociais matérias de opinião, reportagens e depoimentos pessoais sobre práticas on-line percebidas como agressão e violência. Nos Estados Unidos, por exemplo, essas práticas costumam ser englobadas pelo termo shaming ${ }^{23}$, que pode receber, conforme o caso, algum vocábulo adicional que o qualifique e determine o alvo das práticas vexatórias, como em slut-shaming ou fat-shaming. O shaming pode ser imposto por meio de cyberbullying (bullying virtual), revenge porn (pornografia de vingança), discurso de ódio ou linchamento virtual. Essas práticas e o que elas representam parecem ser englobadas conceitualmente por noções como cultura da humilhação e cultura de ódio.

privada, me tornei uma figura publicamente humilhada por todo o mundo. Havia hordas de apedrejadores virtuais [...]. Me chamaram de vadia, de prostituta, de vagabunda e de interesseira. Perdi minha reputação, minha dignidade e quase perdi minha vida. Há 17 anos não havia definição para isso, mas hoje chamamos de cyberbullying ou assédio on-line". As frases são da palestra citada na nota 18 , mas aqui cito trechos traduzidos e citados no site brasileiro da BBC, em 20 de março de 2015. Disponível em: <http://www.bbc.com/portuguese/noticias/2015/03/150320_monica_lewinsky_ted $>$. Acesso em: 07 maio 2017.

22 Em dezembro de 2013, Justine Sacco, prestes a embarcar em um voo de 12 horas para a África do Sul, escreveu no Twitter uma brevíssima mensagem, um tweet (ou tuíte): "Going to Africa. Hope I don't get AIDS. Just kidding. I'm white!” (Indo para a África. Espero não pegar Aids. Estou brincando. Sou branca!"). Por causa desse tuíte, quando desembarcou, foi recebida com hostilidade já no aeroporto, o hotel em que havia feito reservas teria informado que não teria como "garantir sua segurança”, e sua família teria se declarado preocupada de que pudesse ter sua reputação política prejudicada na cidade por causa dela. No Twitter, o tuíte de Justine já havia viralizado e os insultos e ameaças a ela se multiplicavam. A isso seguiu-se, no retorno para casa, a demissão, a forçada mudança de residência, a dificuldade para conseguir um novo emprego, o ostracismo social e um quadro depressivo (RONSON, 2016 e 2015). É possível encontrar muitas informações sobre este e outros casos semelhantes, como os de Adria Richards, Alicia Ann Lynch e Monica Lewinsky, só para mencionar alguns dos mais conhecidos em escala internacional. Sobre Justine Sacco: <https:// www.theguardian.com/world/2013/dec/22/pr-exec-fired-racist-tweet-aids-africa-apology >.

23 Ronson (2015 e 2016). 
A insistência no uso do termo cultura nesses discursos parece apontar para o sentido etimológico da palavra, que remete ao cultivo agrícola mais do que para seu sentido antropológico. Que é o cultivo senão o exercício de fazer germinar uma forma viva graças a ações deliberadas baseadas em saberes técnicos e projetos humanos, que progride em conformidade com o investimento (inclusive, de atenção) que recebe, dadas as condições adequadas para que prospere? A cultura do ódio e a cultura da humilhação, nos discursos midiáticos on-line, que são hoje articulados não apenas por especialistas profissionais, mas por todos que - de modo desigual (RAMOS, 2012), tanto nos modos de produção e expressão como, mais ainda, nas possibilidades de circulação e recepção ${ }^{24}$ - expõem sua voz na esfera pública hiperconectada, vêm sendo tratadas como se fossem espécies indesejáveis que lançassem aos bytes suas sementes, poluindo o ambiente das redes e prejudicando o que, sem elas, talvez pudesse ser (ou permanecer) civilizado. A idealização do debate limpo, sem as impurezas (DOUGLAS, 2001) dos mal-entendidos e da virulência humana ${ }^{25}$, parece estar sempre pressuposta nesse tipo de leitura.

\section{Linchamentos virtuais: 0 tribunal da internet}

No amplo espectro discursivo coberto por noções como cultura da humilhação ou cultura do ódio, podemos encontrar o uso recente no Brasil da denominação linchamento virtual, cada vez mais disseminado entre formadores de opinião nas mídias e entre usuários das redes sociais, em situações de conflito na internet. Ainda que, em um determinado caso, no contingente total de mensagens antagônicas recebidas, a quantidade de insultos, ameaças e ações de exposição não consentida da privacidade, por exemplo, sejam

24 Isto é, o mito da horizontalização das relações sociais na rede, da plena democratização das comunicações, desconsidera o fato de que qualquer um pode criar e publicar conteúdos em um canal no YouTube ou em um blog, mas isso não garante qualquer audiência além de, talvez, seus parentes e amigos.

25 Ou, mais provavelmente, de certos humanos, pois é corrente a nostalgia da web dos primeiros tempos, antes da orkutização das redes sociais, ou seja, antes de sua popularização. O que estou dizendo é que muito do pânico moral em torno dos conflitos e eventuais práticas violentas nas redes decorre do mesmo elitismo social que prega a higienização social também nas cidades. 
poucas ou inexistentes, a mobilização de grande número para antagonizar a um só (indivíduo, grupo ou instituição) tem levado à mobilização da analogia com os linchamentos para definir essa situação.

Mais do que, por exemplo, a punição e expiação pela vergonha, como é comum nos Estados Unidos, o que sobressai na figura do linchamento é a desproporção entre erro e punição imposta, principalmente pelo fato de serem muitos reagindo negativamente - julgando e punindo - a um; o fato mesmo do linchamento carecer de uma justificativa (o suposto erro); e sua representação metafórica como surra, pancadas, pedradas, isto é, como agressão física. Embora ações como ridicularização e zombarias possam estar presentes, elas não parecem ser os elementos distintivos das situações classificadas como linchamentos, como o são nos casos de cyberbullying e discurso de ódio. O que, no linchamento, parece humilhar é o reconhecimento, por parte do sujeito, de sua submissão ao medo, decorrente das ameaças e dos efeitos sociais dos julgamentos negativos sobre ele, muitas vezes enunciados por pessoas em posições de grande prestígio na rede.

Os haters povoam a internet desde seu aparecimento. O discurso de ódio, marcadamente ideologizado, tenderia a tomar como objeto de seus ataques características identitárias de indivíduos e grupos, como raça, gênero, identidade sexual, nacionalidade (ou identidade regional), etnia, aspectos físicos em desacordo com os padrões estéticos hegemônicos ou comportamentos que escapem à normatividade. Ele procura acentuar a inferioridade de seu alvo e o caráter inescapável de sua condição, naturalizada. O objeto do linchamento é, ao contrário, não um modo de ser, mas uma ação ou comportamento (atitude, discurso verbal) percebido como decorrente de erro ou transgressão moral, contra o qual se apresentam denúncias que, por mais severas que sejam, admitem correções.

No linchamento realiza-se um julgamento público sobre a presumida transgressão e, ao anúncio-denúncia do transgressor, segue-se uma avalanche de novas publicações que reforçam, reiteram, complementam a primeira e podem culminar em ameaças, insultos e exposição de privacidade. Tudo isso pode ter consequências graves, no desenrolar dos acontecimentos, no 
período que se segue, o que pode incluir, como já vimos, ostracismo social, demissão, depressão, dentre outras. Porém, por maior que seja a desproporção da punição infligida pela coletividade, todos os envolvidos e testemunhas da situação sabem exatamente qual ação disparou a retaliação. É próprio dessas situações a reiteração dos motivos da indignação e o tom de denúncia do erro. Denúncia, julgamento e punição formam o tripé sobre o qual se constitui um linchamento virtual.

Isso não ocorre nas agressões que consistem essencialmente em discurso de ódio. O que teria feito a jornalista Maria Julia Coutinho, que apresentava o quadro de previsão do tempo do Jornal Nacional desde abril de 2015, para ser ridicularizada no Facebook em julho daquele ano, por postagens de comentadores que a chamavam de macaca, lhe atribuíam cara de doméstica, dentre inúmeros outros insultos claramente racistas e elitistas? Lendo atentamente os comentários nessas postagens, como em tantos outros casos semelhantes, não encontramos quaisquer alegações de transgressão ou erro. Nenhum deles a acusa de nada, a única constante nos comentários ofensivos e injuriosos é a referência à sua condição racial. Do mesmo modo, inúmeras pessoas são atacadas por sua religião, identidade sexual, posição ideológica, seu peso e até por seu time de futebol, e não por um ato ou comportamento denunciado, que demandaria julgamento, punição e expiação.

Assim, de certo modo, o linchamento virtual, por mais violento e doloroso que chegue a ser, admite, como todo mecanismo expiatório não letal, a possibilidade de recuperação após a punição. O espancamento verbal e moral, ao contrário do que ocorre na maioria dos casos de linchamento, não costuma ser letal. Ou seja, a pessoa, por mais que fique emocionalmente marcada e socialmente estigmatizada pelo acontecimento, pode, com o tempo, conseguir se dissociar dele e começar de novo; ou contrabalançar sua má ação com iniciativas que mudem sua imagem e procurem resgatar sua credibilidade. Já as vítimas de discurso de ódio são vulneráveis a um ataque que não apresenta justificativa, tampouco oferece possibilidade de expiação (não há culpa atribuída) ou redenção. O ódio não negocia, não deixa qualquer saída. 
O discurso de ódio não quer atacar a credibilidade de alguém em tal ou tal terreno, ele quer é destruir pessoas e grupos em sua integralidade, em sua própria existência: nordestinos, negros, gays, gordos, estrangeiros, feministas. Ser passível de ser incluída em uma, ou mais, dessas categorias identificatórias estigmatizadas é o que torna Maria Júlia Coutinho ou Lola Aronovich ${ }^{26}$ alvos constantes de discurso de ódio, e não alguma de suas ações isoladas, comportamentos habituais ou características pessoais. $\mathrm{O}$ ataque a elas é, na verdade, um ataque a categorias sociais com as quais são identificadas pelo agressor, o que não foi, de modo algum, o que ocorreu com Elika Takimoto ${ }^{27}$, embora isso não impeça que o que começa como linchamento virtual possa terminar em discurso de ódio ou assédio persistente, já descolado da motivação inicial e indiferente à expiação. Assim, podemos afirmar que haveria, sim, um cultivo do ódio, e que este consistiria na práxis adequada à sua naturalização cotidiana, que seria a mesma que sustenta preconceitos e estigmatizações.

\section{Considerações finais}

É preciso que se tenha claro que, quando falamos aqui em exposição pública, não é da outrora utópica comunidade on-line mundial que estamos falando. Cada pessoa ou grupo que se conecta à internet e publica em um blog, site, grupo ou perfil em rede social está inserida em um segmento da Rede (Internet), e sua audiência - seja qual for, buscada e desejada ou não, incluindo-se aí as audiências invisíveis e as potenciais, de que o próprio sujeito pode não estar consciente e sobre as quais não consegue ter controle - será sempre determinada audiência particular.

26 Do blog Escreva, Lola, Escreva, alvo constante de misóginos e antifeministas. Disponível em: $<$ http://escrevalolaescreva.blogspot.com.br/>.

27 Ou, para dar outro exemplo, com a atriz e escritora Fernanda Torres, "mulher branca de classe média", após a publicação, no dia 22 de fevereiro de 2016, do artigo "Mulher” na Folha de São Paulo, pelo qual foi duramente criticada e agredida por comentários em seus perfis nas redes sociais (http://agoraequesaoelas.blogfolha.uol.com.br/2016/02/22/mulher/). 48 horas depois ela se retratou com outro texto, "Mea Culpa", no mesmo jornal, no qual pedia às mulheres "profundas desculpas” por seu erro. Disponível em: <http://agoraequesaoelas.blogfolha.uol.com. br/2016/02/24/mea-culpa/>. 
Da mesma forma, para tentarmos compreender o que se passaria na experiência da agressão, da desmoralização pública e dos danos ou perda da reputação, precisamos ir além da caracterização geral dos públicos em rede (BOYD, 2007) e da hiperconectividade das redes sociais. Precisamos levar em conta que o reconhecimento que se busca, a audiência que se deseja, a rejeição que se teme não é, na mesma medida e intensidade, a de todos, um público vago e genérico, mas sim aquela dos pares com quem interagimos rotineiramente, dos conhecidos que manifestam por nós admiração e multiplicam nossos posts, das figuras públicas a quem admiramos e temos como referências. A percepção da Internet como rede global está fundamentada na possibilidade técnica real de sua estruturação e alcance, mas nada nos informa sobre como se concretizam nossas conexões e quais redes vamos, de fato, constituir por meio de nossos agenciamentos e práticas concretas. A Rede total dada, tomada como entidade em si, virtualmente global, não é e jamais poderia ser a nossa rede, ou melhor, nossas redes. Estas, na internet como na vida, somente vêm a existir na medida em que as criamos e as mantemos por meio de nossas ações, e seu alcance, como suas fronteiras, permanece instável, variando ao passo delas, bem como dos efeitos das ações dos demais atores sobre nós.

Ainda assim, a escalabilidade dos conflitos que configuram o linchamento virtual certamente não seria a mesma sem os "públicos em rede" e a consequente hiperconectividade que eles trazem, no sentido apontado por danah boyd.

Sobre a dimensão temporal dos linchamentos virtuais - em comum com eventos próximos, como a pornografia de vingança e demais formas de shaming -, pesam impressões aparentemente contraditórias. Por um lado, diz-se que logo estarão roendo outro osso, ou seja, os escândalos, dramas, denúncias sucedem-se em ritmo acelerado nas redes sociais e nisso haveria uma promessa de que vai passar logo, seja lá qual for o volume do escândalo e gravidade das consequências; por outro lado, também se diz, especialmente nessas situações, que a internet nunca esquece, o que já se constitui hoje em máxima do senso comum, mas também em preocupação que mobiliza, por 
exemplo, juristas ${ }^{28}$ em busca de soluções que assegurem o direito à retirada da Rede de postagens prejudiciais e da criação de mecanismos que inibam esse tipo de ação e forneça garantias à privacidade.

Nesse plano, o que parece assustar e inflamar opiniões nos linchamentos virtuais - e na cultura da humilhação e do ódio, em geral - não são tanto as consequências individuais - para a reputação, por exemplo - quanto a tomada de consciência a que elas nos obrigam do pouco ou nenhum controle que podemos exercer sobre nossas ações, interações e suas repercussões, e sobre o dinamismo global das redes. $\mathrm{O}$ reconhecimento que alcançamos e de que gozamos nessas redes permanece refém de dinâmicas que lhes são intrínsecas e que ainda pouco compreendemos.

Neste sentido, o possível aumento da desconfiança e da percepção de risco nessas redes on-line vem sendo emulado por cruzadas morais promovidas por agentes sociais como governos, empresários, juristas, pesquisadores, dentre outros, e veiculadas pelas mídias e seus formadores de opinião - inclusive, nas redes sociais e internet em geral. Essas campanhas - raramente assumidas como tais e em alguns casos reproduzidas de modo irrefletido, como quando reproduzimos o discurso dos riscos, tomando as exceções (os casos graves) pela regra - tentam vender o combo censura \& regulamentação, oferecendo como brinde suposta tranquilidade.

Assim, faria sentido o emprego metafórico da noção de linchamento, pois o objetivo parece ser mesmo o de "carregar nas tintas" e mostrar que estaríamos convivendo com a barbárie pós-orkutização (popularização) das redes sociais. Outro termo muito utilizado, aliás - barbárie -, para descrever cenários de linchamentos virtuais. Isso não deixa de ser irônico em um país como o Brasil, no qual jovens negros são amarrados em postes e surrados até a morte, assim como travestis e supostas adeptas de "magia negra" - o que pode ser eufemismo para se referir às religiões de matriz afro-brasileira, outro segmento minoritário que não precisou esperar pela invenção das redes sociais para tornar-se alvo de discurso de ódio. Nenhuma campanha viral

28 O Direito ao Esquecimento na Internet surge nesse quadro (FERRIANI, 2016). 
no Facebook seria capaz de produzir como resultado um linchamento nas ruas se já não houvesse "lá fora" uma sociedade pronta para espancar aqueles a quem cotidianamente estigmatiza.

Como já afirmamos, a internet não é, do ponto de vista social, uma rede dada ou ambiente pronto no qual "entramos", ao qual apenas adicionamos nossa presença; nossas redes dentro da Rede apenas existem em sua singularidade e concretude em um processo por meio do qual as vamos constituindo na medida em que as delineamos e vivenciamos através das conexões que estabelecemos. Estar na rede é abrir-se a conexões múltiplas e compor configurações únicas. Se hoje não gostamos do que vemos nos comentários das publicações de notícias, por exemplo, é improvável que a solução esteja no realismo identitário, na limitação da liberdade de expressão, na exacerbação da mútua vigilância, na troca de acusações e caçadas a bruxas. Mais produtivo seria examinarmos o que temos afinal cultivado em nossas experiências sociais, nas redes on-line e "fora" delas.

\section{REFERÊNCIAS}

1. BOYD, D. Why Youth (Heart) Social Network Sites: the role of networked publics in teenage social life. MacArthur Foundation Series on Digital Learning - Youth, Identity, and Digital Media Volume (ed. David Buckingham). Cambridge: MIT Press, 2007.

2. DERY, Mark. Flame Wars. The Discourse of Cyberculture. Durham e Londres: Duke University Press, 1994.

3. DOUGLAS, M. Pureza e Perigo. São Paulo: Editora Perspectiva, 1976 [1966].

4. FERRIANI, Luciana de Paula Assis. O Direito ao Esquecimento como um Direito da Personalidade. Tese (Doutorado em Direito) - Pontifícia Universidade Católica de São Paulo, São Paulo, 2016.

5. JUNGBLUT, Airton. Práticas ciberativistas, agência social e ciberacontecimentos. Vivência: Revista de Antropologia, Natal, UFRN/DAN/PPGAS, v. 1, n. 45, jan./jun. 2015, 2015.

6. MARTINS, José de Souza. Linchamentos. A Justiça Popular no Brasil. São Paulo: Editora Contexto, 2015. 
7. PETROSILlO, Isabela Rangel. Esse nu tem endereço. O caráter humilhante da nudez e da sexualidade feminina em duas escolas públicas. 2016. 133 f. Dissertação (Mestrado em Antropologia) - PPGA/UFF, Niterói, 2016.

8. RAMOS, Jair. Subjetivação e poder no Ciberespaço: da experimentação à convergência identitária na era das redes sociais. Vivência: Revista de Antropologia, Natal, UFRN/DAN/PPGAS, v. 1, n. 45, jan./jun. 2015.

9. T_ Toma que o aborto é teu: a politização do aborto em jornais e na web durante a campanha presidencial de 2010. Revista Brasileira de Ciência Política, Brasília, n. 7, p. 55-82, jan./abr. 2012.

10. RECUERO, Raquel. Atos de ameaça à face e à conversação em redes sociais na internet. In: PRIMO, Alex (Org.). Interações em Rede. Porto Alegre: Sulina, 2013.

11. RONSON, Jon. A vida por um tuíte. Como uma frase infeliz pode destruir uma pessoa. Revista Piauí, Edição 102 (questões virtuais), mar. 2015. Disponível em: <http://piaui.folha.uol.com.br/materia/a-vida-por-um-tuite/>. Acesso em: 04 nov. 2016.

12. So you've been publicly shamed. Londres: Picador, 2015.

13. SIMMEL, Georg. Conflict. In: LEVINE, Donald N. (Ed.). Georg Simmel. On Individuality and Social Forms. Chicago: The University of Chicago Press, 1971. p. 70-95.

14. SINGER, Helena. Discursos Desconcertados. Linchamentos, Punições e Direitos. Humanos. São Paulo: Humanitas/FFLCH/USP/Fapesp, 2003.

15. SOARES, Luiz Eduardo. Violência e Política no Rio de Janeiro. Rio de Janeiro: Relume-Dumará/ISER, 1996.

16. THOMPSON, Kenneth. Moral Panics. Londres: Routledge, 2002 [1998].

\section{Sites:}

17. GOMES, Wilson. Linchando Elika Takimoto. DCM, 04 maio 2017. Disponível em: <http://www.diariodocentrodomundo.com.br/linchando-elika-takimoto-por-wilson-gomes/>. Acesso em: 07 maio 2017.

18. GRUNER, Clóvis. O ativismo das redes produz monstros. Medium, 05 maio 2017. Disponível em: <https://medium.com/@clvisgruner/o-ativismo-lombrosiano-produz-monstros-9aa51bce0d9f $>$. Acesso em: 07 maio 2017.

19. LAU, Fábio. Os ataques a Elika Takimoto não fazem o menor sentido. Conexão Jornalismo, 04 maio 2017. Disponível em: <http://www.conexaojornalismo. com.br/colunas/cultura/novasmidias/os-ataques-a-elika-takimoto-nao-fazem-o-menor-sentido-67-46977>. Acesso em: 07 maio 2017. 
20. MIGUEL, Luís Felipe. Por que Elika Takimoto saiu do Facebook? Esquerda Caviar, 03 maio 2017. Disponível em: <http://caviaresquerda.blogspot.com. br/2017/05/por-que-elika-takimoto-saiu-do-facebook.html>. Acesso em: 07 maio 2017.

21. TAKIMOTO, Elika. Até um dia, Facebook. Jornal GGN, 04 maio 2017. Disponível em: <https://jornalggn.com.br/noticia/ate-um-dia-facebook-por-elika-takamoto>. Acesso em: 07 maio 2017.

22. _. Minha Vida é um Blog Aberto. Disponível em: $<$ https://elikatakimoto. com/>. Acesso em: 04 maio 2017. 